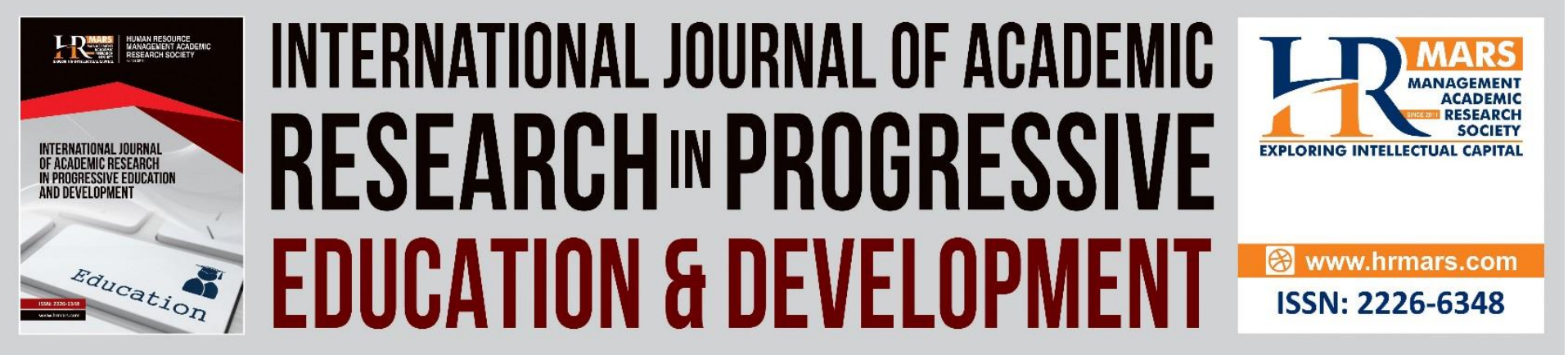

\title{
Assessment of the Impact of Students' Mode of Admission into University and their Academic Achievement in Nigeria
}

Emaikwu, Sunday Oche

To Link this Article: http://dx.doi.org/10.6007/IJARPED/v1-i4/12001

DOI: $10.6007 /$ IJARPED/v1-i4/12001

Received: 19 September 2012, Revised: 23 October 2012, Accepted: 02 November 2012

Published Online: 24 November 2012

In-Text Citation: (Emaikwu, 2012)

To Cite this Article: Emaikwu, S. O. (2012). Assessment of the Impact of Students' Mode of Admission into University and their Academic Achievement in Nigeria. International Journal of Academic Research in Progressive Education and Development, 1(4), 118-131.

Copyright: (c) 2012 The Author(s)

Published by Human Resource Management Academic Research Society (www.hrmars.com)

This article is published under the Creative Commons Attribution (CC BY 4.0) license. Anyone may reproduce, distribute, translate and create derivative works of this article (for both commercial and non-commercial purposes), subject to full attribution to the original publication and authors. The full terms of this license may be seen

at: http://creativecommons.org/licences/by/4.0/legalcode

Vol. 1(4) 2012, Pg. 118 - 131

http://hrmars.com/index.php/pages/detail/IJARPED

JOURNAL HOMEPAGE

Full Terms \& Conditions of access and use can be found at

http://hrmars.com/index.php/pages/detail/publication-ethics 


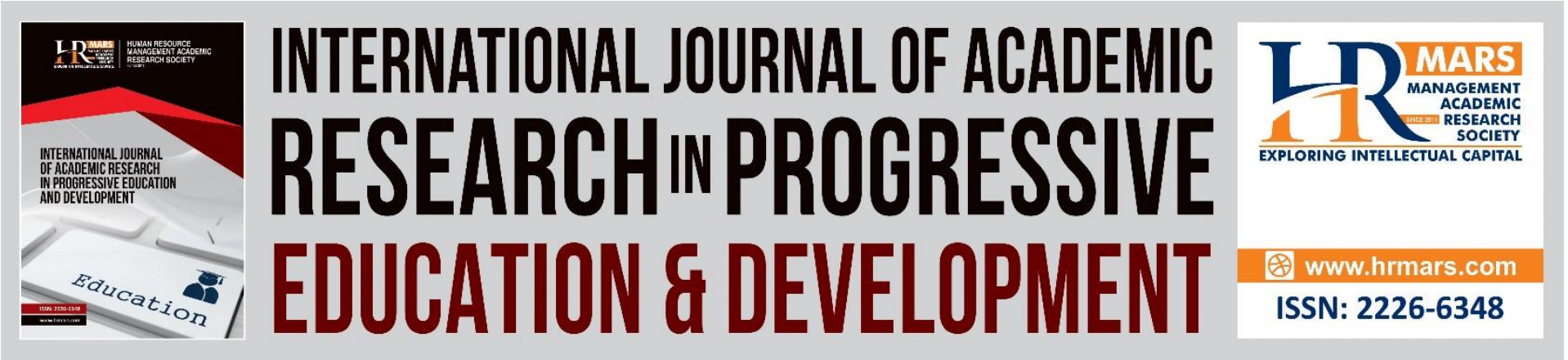

\title{
Assessment of the Impact of Students' Mode of Admission into University and their Academic Achievement in Nigeria
}

\author{
Emaikwu, Sunday Oche PhD \\ Department of Educational Foundations \& General Studies, Federal University of \\ Agriculture, P.M.B. 2373 Makurdi, Benue State, Nigeria \\ Email: emaikwuoche@yahoo.com
}

\begin{abstract}
The purpose of this research work was to assess the impact of students' mode of admission into university and their academic achievement in Nigeria. The design of the study was an ex post facto research design. To carry out the study four research questions were answered using mean and standard deviation while four hypotheses were tested using analysis of variance and t-test statistic. The sample for the study consisted of 253 students randomly selected from two universities in Benue State using proportionate stratified random sampling technique. The results indicated that there was no statistical significant difference in the mean academic achievement of students who were admitted into the university through unified tertiary matriculation examination, remedial programme and direct entry admissions. There was statistical significant difference in the mean academic achievement of male and female students and that the academic achievement of male students was higher than their female counterparts based on the three modes of admission. The paper recommends that university authority should continue to admit students into the university through the three modes of admission at reasonable proportion to enhance academic excellence of the citizenry. Efforts should be made by the university authority to ensure that none of the categories of students is discriminated against so as to produce good quality graduates. Above all, attempt should be made to reduce the academic achievement gap between male and female students in the universities as a means of addressing issues of imbalance.
\end{abstract}

Keywords: University, Academic Achievement, Mode of Admission, Remedial Admission, Direct Entry Admission, Unified Tertiary Matriculation Examination

\section{Introduction}

Many persons seem to be perplexed as to what factors are actually responsible for the fall in the standard of students' achievement in universities in Nigeria. This puzzled state has eventually led many to attribute the abysmal fall in achievement to: poor condition of service for lecturers; inadequate supply of facilities and equipment; lack of motivation; wrong method of teaching and admission of incompetent candidates into universities (Emaikwu \& Nworgu, 2005). Onah (2012); Emaikwu (2012) affirmed that the fall in standard of achievement by students at all levels of education has been awfully reported and 
acknowledged by all and sundry in Nigeria. To catch a glimpse of evidence of the terrible fall in the standard of performance in Nigeria, Agbo (2012) reported in the 'Nation Newspaper' of 4th June 2012 thus:

The ridiculous reduction in cut-off point for admission into Nigerian universities is at variance with the standard of excellence already set by some universities. For Joint Admission Matriculation Board (JAMB) to lower the cut-off mark to 180 out of 400, which translates to a mere 45 per cent, is to assume that all the Nigerian universities would stoop so low to woo failed students as their potential candidates for admission. With this policy in place in Nigeria, the international community will see nothing good in Nigerian university education which is now open to all - the good, the bad and the ugly. Unless we go back to that noble system, more than 60 per cent of candidates admitted into our universities will always be of poor quality and this will surely create problems for their teachers who bear the brunt and pains of teaching "unteachable" students (p. 10).

Reaffirming this deplorable condition of university education, Adekunle (2012) reported in the 'Nation Newspaper' of 9th September 2012 that university education is at a crossroad in Nigeria and opined that it was only in 1973 that four Nigerian universities were rated among the best 20 in Africa and today, none of them is among the best 30 in Africa, while none is among the best 1000 in the world.

The public opinion about the appalling standard of performance of students graduating from universities in Nigeria in the recent time has reached an alarming crescendo. More disturbing is the common observation that many graduates from universities are being rejected by the labor market because of low academic competence. Hitherto, the general untidiness in the uncoordinated system of admissions into universities and their attendant problems were sufficient causes for concern to all and sundry in Nigeria. Despite the establishment of the JAMB which is Nigeria's official entrance examination board aimed at regulating admission process, some educationists have argued that the incompetence of many university students after graduation is precipitated by the selection procedure of JAMB which fails to control the number and quality of candidates being admitted into the universities annually. This problem of incompetency of university graduates in Nigeria has been partly blamed on the Board's system of admission.

Presently there are three categories of students being admitted into university undergraduate programs in Nigeria and they include those that pass through the unified tertiary matriculation examination (UTME) conducted by Joint Admission and Matriculation Board (JAMB), direct entry admission and those who pass through remedial programme being run by individual university respectively. All the three groups have varying academic experiences and hence the basis for differences in their modes of entry into university. There are variations in the ordinary level qualification of the remedial programme students, ranging from no credit to four credit passes. Whereas the remedial students with three or four credit level passes at the ordinary level lacked experience of the university courses, the problem seem more complicated for the remedial students with no credit level at all. Hence this could reflect in their academic achievement when admitted into the university programs. 
Hitherto direct entry admission is Nigeria's official advanced entrance into universities by using certificates such as national certificate in education, national diploma and other higher certificates. One of the problems associated with the direct entry mode was the non uniformity in the national certificate in education, ordinary national diploma and higher national diploma holders, yet they are all considered to have the same experience during admission and subsequent departmental placement. National University Commission (1999) affirms that many colleges of education operate outside the National Commission for Colleges of Education (NCCE) guidelines, thus leading to variation in experiences among national certificate in education holders. Moreover, since the direct entry candidates were certified internally to the extent that each college of education, polytechnic and college of Agriculture and so on, sets and conducts her own certificate examinations for her students; one could doubt the validity of such examinations.

Contrary to expectation that all students admitted into the university irrespective of the mode of entry will be able to cope with the academic rigors, some students drop out on the way without graduating from the university. Many students change their courses and while others spend extra years before graduating; and more often some students end up with third class and pass degrees from many universities in Nigeria thereby compounding their chance of gainful employment. The belief of people over which mode of entry is better in terms of university academic achievement of students is different from one group to another. There have been conflicting findings on the predictive strength of modes of entry in forecasting performance in university examinations. Mgbake (2006) stated that students' academic success is largely a function of the amount of efforts put into study and not necessarily as a result of mode of entry into the university. Agada (2008) reported that students' study techniques and attitude to the study of a particular course among other factors influence their academic performance. Commenting on the attitude of students as a factor influencing academic performance he stated that achievement of qualitative education and in fact success in all worthwhile endeavors requires effort. He reported that students ought to put more efforts in their academic activities which include concentration in their studies, frequent revision of work already done and diligence in doing assignments. There is a time for everything under the sun and hence the time that students spend while in training in school is the time to work hard so as to achieve a better learning outcome.

Long (2005) found that there is no significant difference in the performance of three groups in the courses taught in the faculty of science. Adeniyi (2004) reported that unified tertiary matriculation examination candidates performed poorest in their university examination and this is because they may be too young to face an expanded computer-based-scientificallyoriented curriculum and that they could also have the problems of lack of experience and tender age which affect their academic achievements. This he said, could be due to poor linkage between what is being taught in the university and what was known before entry into university from the secondary school level. I paye (2004) reported that in degree examination, direct entry students performed better than preliminary students in arts subjects whereas the remedial students did better in science and technical subjects.

Ezema (2006) compared the degree results of direct entry students, unified tertiary matriculation students and remedial students and reported that for the five academic sessions studied there was no significant difference between the cumulative grade point 
average of the three groups prior to their degree examinations. Ojo (2005) reported that direct entry students were superior to their remedial and university matriculation examination students in academic achievement. The most evidence of superiority of direct entry students is the achievement criterion of degree completion rate. This indicates that the rate of students' wastage is more among remedial entrance students. Supporting this finding is the observation made by Angulu (2007) that students who enter the university with high school certificate performed better in the second and third year than those admitted into the university via preliminary programme since they are usually more prepared for the university academic work. Nevertheless, he recommended that remedial programme be allowed to stay as a means of meeting up admission quota and addressing issues of imbalance.

The issue of gender differences in achievement has been in existence for quite a long time. Research evidence abounds to show that girls are not achieving well as expected like boys in universities (Becker, 2005; Finn, 2008 \& Erickson, 2009). Aiken (2007) reported that males are superior to females in academic achievement. The evidence of the existence of gender gap in American schools was also attested by Glenn and Ashley (2009) who affirmed that there is a large gender gap that widens dramatically at percentiles above those that can be examined using standard data sources. They submitted that an analysis of unobserved heterogeneity indicates that there is only moderate variation in the gender gap across schools and that the highest achieving girls in the U.S. are concentrated in a very small set of elite schools, suggesting that almost all girls with the ability to reach high achievement levels are not doing so. On the contrary Hyde and Mertz (2009) reported that there is no gender gap among 99th percentile Asian Americans in Minnesota. However, Fryer and Levitt (2009) noted that the gender gap in their result is very consistent across demographic groups and hence their basic conclusion is that there is variation in the gender gap across schools, but that the magnitude of the variation is not very large. Guiso, Monte, Sapienza, and Zingales (2008) examine the relationship between test scores and measures of cultural, political, and economic gender equity. They found that the gender gap in average scores is smaller in countries with greater gender equity. Kelly (2007) asserted that boys are ahead of girls, in every branch of science with the largest difference being in mathematics and practical test. Will this difference in achievement exist based on mode of admission into university in Nigeria?

The academic performance of students admitted into universities has been an issue of great concern to many people who are interested in education industry in Nigeria. The decay in the educational system calls for attention and hence the search for the most desirable mode of selecting candidates for admission into Nigerian universities continues unabated. Based on the inconsistency of previous reports the scenario shows that performance may or may not be a function of the mode of entry of students into the university. This study therefore assesses the impact of students' mode of admission into University and their academic achievement.

\section{Research Questions}

To carry out the study, these research questions were answered:

1. What is the mean academic achievement of the students who are admitted into the university through unified tertiary matriculation examination, remedial programme and direct entry? 
2. What is the mean academic achievement of male and female students who are admitted into the university through unified tertiary matriculation examination?

3. What is the mean academic achievement of male and female students who are admitted into the university through direct entry admission?

4. What is the mean academic achievement of male and female students who are admitted into the university through remedial programme?

\section{Research Hypotheses}

The following hypotheses were formulated to guide the study and were tested at $5 \%$ level of significance;

1. There is no statistical significant difference in the mean academic achievement of students who are admitted into the university through unified tertiary matriculation examination, remedial programme and direct entry.

2. There is no statistical significant difference in the mean academic achievement of male and female students who are admitted into the university through unified tertiary matriculation examination.

3. There is no statistical significant difference in the mean academic achievement of male and female students who are admitted into the university through direct entry admission

4. There is no statistical significant difference in the mean academic achievement of male and female students who are admitted into the university through remedial programme.

\section{Research Methodology}

The design of the study is an ex post facto research design. The research was carried out at the Federal University of Agriculture, Makurdi and Benue State University Makurdi. The population of the study consisted of all the third year students in the College of Agricultural and Science Education at the Federal University of Agriculture Makurdi and all third year students in the Faculty of Education at Benue State University Makurdi. A sample of 253 students was selected from the population bearing in mind that it included the three modes of entry into university that were the concern of this study. Precisely the sample consisted of 100 remedial students, 120 unified matriculation examination students and 33 direct entry students. A proportional stratified random sampling technique was used in the selection of the sample to ensure that all the three modes of admission into the university were fully represented. In carrying out the study, information about each student was extracted from the records kept in their files at their various departments. To find out the academic achievement of the three categories of students, their academic performances at the end of their third year of study were identified and compared. The data concerning the sampled students were collected from their departments through the students' data files by the researcher. The students' 300 level results of 2010/2011 were collected in the subgroups of direct entry, university matriculation examination and remedial admissions. The research questions posed were answered using mean and standard deviation while the hypotheses formulated were tested using analysis of variance and t-test statistic. 
DEVELOPMENT

Vol. 1, No. 4, 2012, E-ISSN: $2226-6348$ C 2012 HRMARS

\section{Results of The Findings}

Research question 1: What is the mean academic achievement of students who are admitted into the university through unified tertiary matriculation examination, remedial programme and direct entry admissions?

Research hypothesis 1: There is no statistical significant difference in the mean academic achievement of students who are admitted into the university through unified tertiary matriculation examination, remedial and direct entry admissions.

Table 1: Academic Achievement of Students Based on Modes of Admission into University

\begin{tabular}{lccc}
\hline Mode of entry & $\mathrm{N}$ & Mean & Standard deviation \\
\hline UTME & 120 & 2.99 & 0.90 \\
Remedial & 100 & 2.86 & 0.86 \\
Direct entry & 33 & 2.95 & 0.73 \\
\hline
\end{tabular}

Table 1 shows the mean and standard deviation of the academic achievement of students based on their modes of admission into the university. To check if the differences in the mean academic achievements of students obtained based on the three modes of admission were statistically significant, the corresponding hypothesis was therefore tested and the result is as presented in Table 2.

Table 2: F-ratio Comparison of Students' Achievement Based on Unified Tertiary Matriculation Examination, Remedial Programme and Direct Entry Admissions into University

\begin{tabular}{lccccc}
\hline $\begin{array}{l}\text { Source of } \\
\text { Variation }\end{array}$ & $\begin{array}{c}\text { Sum of } \\
\text { squares }\end{array}$ & DF & $\begin{array}{c}\text { Variance } \\
\text { Estimate }\end{array}$ & F-ratio & F-critical \\
\hline $\begin{array}{l}\text { Between } \\
\text { Groups }\end{array}$ & 212.25 & 2 & 106.125 & 2.951 & 3.00 \\
\hline $\begin{array}{l}\text { Within } \\
\text { Groups }\end{array}$ & 8987.86 & 250 & 35.951 & & \\
\hline Total & $\mathbf{9 2 0 0 . 1 1}$ & $\mathbf{2 5 3}$ & & & \\
\hline
\end{tabular}

From Table 2, the F-ratio is 2.951 and the critical value of $\mathrm{F}$ for 2 and 250 degrees of freedom is 3.00. The obtained F-ratio of 2.951 is lower than the critical F-table value of 3.00; hence F is not statistically significant and therefore the null hypothesis is accepted. This implies that there is no statistical significant difference in the mean academic achievement of students who are admitted into the university through unified tertiary matriculation examination, remedial programme and direct entry. Therefore students do not differ significantly in their academic achievement based on the mode of admission into the university. Any physical differences observed amongst the mean academic achievement of students who are admitted into the university through unified tertiary matriculation examination, remedial programme and direct entry admission are such that might have arisen from sampling errors or any other variations in the study.

There is the need to calculate the effect size for this one-way independent analysis of variance (ANOVA) which yielded no statistical significant result. Effect size statistic provides an 
indication of the magnitude of the difference between the groups being statistically compared. The procedure for calculating eta squared for analysis of variance is provided by the formula:

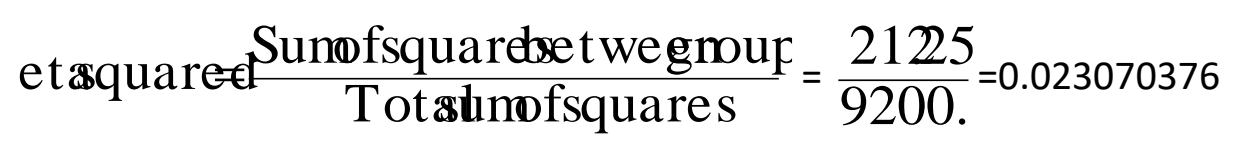

The guidelines for interpreting the value of eta squared are: $0.01=$ small effect, $0.06=$ moderate effect, $0.14=$ large effect. In this hypothesis, we can see that the effect size of 0.0230703376 is a small effect size. Expressed as a percentage, (i.e. multiply the effect size by 100), 2.3 per cent of the variance in the dependent variable could be explained by the independent variable.

Research question 2: What is the mean academic achievement of male and female students who are admitted into the university through unified tertiary matriculation examination?

Research hypothesis 2: There is no statistical significant difference in the mean academic achievement of male and female students who are admitted into the university through unified tertiary matriculation examination.

Table 3: Mean, variance and standard deviation as well as t-test statistic of male and female students who are admitted into the university through unified tertiary matriculation examination

\begin{tabular}{lcccccccc}
\hline Sex & Mean & Variance & SD & $\mathbf{N}$ & df & $\alpha$ & t-cal & t-critical \\
Male & 3.49 & 0.6889 & 0.83 & 80 & & & & \\
Female & $\mathbf{2 . 4}$ & 0.94 & 0.97 & 40 & 118 & 0.05 & 5.461 & 1.96 \\
\hline
\end{tabular}

Table 3 above shows that the mean score of 3.49 of the male students who were admitted into the university through unified tertiary matriculation examination is higher than that of their female (2.49) counterparts. The result of the hypothesis indicated that the t-calculated value of 5.461 exceeded that of the t-critical value of 1.96; therefore the null hypothesis is rejected. This implies that there is a significant difference in the mean academic achievement between male and female students who were admitted into the university through unified tertiary matriculation examination at $5 \%$ level of significance. The result shows that male students who were admitted into the university through unified tertiary matriculation examination performed better than their female counterparts who were equally admitted into the university through unified tertiary matriculation examination.

There is the need to calculate the effect size for this independent sample t-test statistic which yielded a statistical significant result. The procedure for calculating eta squared for the independent t-test statistic in Table 3 above is provided by the formula: et $\$$ quare $\frac{t^{2}}{t^{2}+\left(n_{1}+n_{2}-2\right)}$ From Table 3, the $t$-calculated is 5.461, $n_{1}=80$ and $n_{2}=40$, the eta squared could be calculated by replacing the values in the formula. 
Hence the et $\$$ quare $\frac{t^{2}}{t^{2}+\left(n_{1}+n_{2}-2\right)}=\frac{(5.461}{(5.46) 1+(80+40-2)}=0.2017454$

The guidelines for interpreting the value of eta squared are: $0.01=$ small effect, $0.06=$ moderate effect, $0.14=$ large effect. In this hypothesis, we can see that the effect size of 0.2017454499 is a large effect size. Expressed as a percentage, (i.e. multiply the effect size by 100), 20.2 per cent of the variance in the dependent variable could be explained by the independent variable.

Research question 3: What is the mean academic achievement of male and female students who are admitted into the university through direct entry admission?

Research hypothesis 3: There is no statistical significant difference in the mean academic achievement of male and female students who are admitted into the university through direct entry admission

Table 4: Mean, variance and standard deviation as well as t-test statistic of male and female students who are admitted into the university through direct entry admission

\begin{tabular}{lcccccccc}
\hline Sex & Mean & Variance & SD & $\mathbf{N}$ & df & $\alpha$ & t-cal & t-critical \\
Male & 3.4 & 0.64 & 0.80 & 20 & & & & \\
Female & 2.5 & 0.44 & 0.66 & 13 & 31 & 0.05 & 3.52 & 2.02 \\
\hline
\end{tabular}

Table 4 above shows that the mean score (3.4) of the male students who were admitted into the university through direct entry admission is higher than that of their female (2.5) counterparts. The result of the hypothesis indicated that the $t$ - calculated value of 3.52 exceeded that of $t$-critical value of 2.02; therefore the null hypothesis is rejected. This implies that there is a statistical significant difference in the mean academic achievement of male and female students who are admitted into the university through direct entry admission at $5 \%$ level of significance. The result shows that male students who were admitted into the university through direct entry admission performed better than their female counterparts who were equally admitted into the university through direct entry admission. There is the need to calculate the effect size for this independent sample t-test statistics which yielded a statistical significant result. The eta squared for the independent t-test statistic in Table 3 above where the t-calculated value $=2.02, n_{1}=20$ and $n_{2}=13$, is $\frac{(3.5)}{(3.5)+(20+13-2)}=0.285556$

In this hypothesis, we can see that the effect size of 0.285556252 is a big effect size. Expressed as a percentage, (i.e. multiply the effect size by 100), 28.6 per cent of the variance in the dependent variable could be explained by the independent variable

Research question 4: What is the academic performance of male and female students who are admitted into the university through remedial programme?

Research hypothesis 4: There is no statistical significant difference in the mean academic achievement of male and female students who are admitted into the university through remedial programme. 
Table 5: Mean, variance and standard deviation as well as t-test statistic of male and female students who are admitted into the university through remedial programme

\begin{tabular}{lcccccccc}
\hline Sex & Mean & Variance & SD & $\mathbf{N}$ & df & $\alpha$ & t-cal & t-critical \\
Male & 3.43 & 0.49 & 0.70 & 70 & & & & \\
Female & 2.29 & 1.0404 & 1.02 & 30 & 98 & 0.05 & 3.58 & 1.98 \\
\hline
\end{tabular}

Table 5 above shows that the mean academic score (3.43) of the male students who were admitted into the university through remedial programme is higher than that of their female (2.29) counterparts. The result of the hypothesis indicated that the $t$ - calculated value of 3.58 exceeded that of $t$-critical value of 1.98; therefore the null hypothesis is rejected. This implies that there is a statistical significant difference in the mean academic achievement of male and female students who are admitted into the university through remedial programme at $5 \%$ level of significance. The result shows that male students who were admitted into the university through remedial programme performed better than their female counterparts who were equally admitted into the university through remedial programme.

The effect size for this independent sample t-test statistic which yielded a statistical significant result could be calculated by replacing the values of the $t$-calculated $=3.58, n_{1}=70$ and $n_{2}=30$ in the formula to get et aquare $\frac{t^{2}}{t^{2}+\left(n_{1}+n_{2}-2\right)}=\frac{(3.5)}{(3.5)(70+30-2)}=0.1156543 t$ In this hypothesis, we can see that the effect size of 0.115654 is a moderate effect size. Expressed as a percentage, (i.e. multiply the effect size by 100), 11.6 per cent of the variance in the dependent variable could be explained by the independent variable

\section{Discussion of Findings}

There has been much controversy as to which category of students performs better in the university examination and to which mode of admission more emphasis should be placed in the university admission. From Table 2, the F-ratio was 2.951 and the critical value of $\mathrm{F}$ for 2 and 250 degrees of freedom was 3.00. The obtained F-ratio of 2.951 was lower than the critical F-table value of 3.00; hence F was not statistically significant and therefore the null hypothesis was accepted. The findings of this study showed that there was no statistical significant difference in the mean academic achievement of students who were admitted into the university through unified tertiary matriculation examination, remedial programme and direct entry. Therefore students did not differ significantly in their academic achievement based on the mode of admission into the university. Any physical differences observed amongst the mean academic achievement of students who were admitted into the university through unified tertiary matriculation examination, remedial programme and direct entry admission were such that might have arisen from sampling errors or any other variations in the study. For the very fact that there was no statistical significant difference in the mean academic achievement of students based on the mode of entry into the university, clearly depicts that the achievement of the students in university education depends on the experiences of students under the influence of the university instructional environment. The finding of this study is in affirmative with Ezema (2006) who compares the results of direct entry students, unified tertiary matriculation examination students and remedial students 
and reports that for the five academic sessions studied there was no significant difference between the cumulative grade point average of the three groups prior to their degree examinations. Long (2005) also reports that there was no significant difference in the mean performance of three groups of students based on the mode of entry into the university. Several factors must have contributed to non-significant difference in the mean academic achievement of the three groups of students. The result of this finding supports the submission of Mgbake (2006) who states that students' academic success is largely a function of the amount of efforts put into study and not necessarily as a result of mode of entry into the university. Agada (2008) affirms that students' study techniques among other factors influence their academic achievement in universities. Commenting on the factors influencing academic performance of students, he stated that achievement of qualitative education and in fact success in all worthwhile endeavors requires effort. He reported that students ought to put more efforts in their academic activities which include concentration in their studies, frequent revision of work already done and diligence in doing assignments. Sequel to this it could be observed that there is a time for everything under the sun and hence the time that students spend while in training in school is the time to work hard so as to achieve a better learning outcome.

The results of the hypotheses 2, 3 and 4 indicated that the $t$ - calculated values exceeded that of $t$-critical values and therefore the three null hypotheses were rejected. This therefore implies that there was a statistical significant difference in the mean academic achievement of male and female students who were admitted into the university through direct entry, remedial programme and unified tertiary matriculation examination admissions at $5 \%$ level of significance. In other words, the academic achievement of male students was higher than that of their female counterparts based on the three modes of admission. The issue of gender differences in achievement has been in existence for quite a long time. It has been shown that gender difference in performance exists with the observation that boys dominate in many aspects of the school subjects. This work affirms the earlier report by Kelly (2007) who asserts that boys are ahead of girls, in every branch of science with the largest difference being in mathematics and practical test. Research evidence also shows that girls are not achieving well as expected like boys in school system (Becker, 2005; Finn, 2008 \& Erickson, 2009). Aiken (2007) reports that male student is often superior to female student in academic achievement in schools. The evidence of the existence of gender gap in American schools is also attested by Glenn and Ashley (2009) who affirm that there is a large gender gap that widens dramatically at percentiles above those that can be examined using standard data sources. They submit that an analysis of unobserved heterogeneity indicates that there is only moderate variation in the gender gap across schools and that the highest achieving girls in the U.S. are concentrated in a very small set of elite schools, suggesting that almost all girls with the ability to reach high achievement levels are not doing so. Guiso, Monte, Sapienza, and Zingales (2008) examine the relationship between test scores and measures of cultural, political, and economic gender equity and they discover that the gender gap in average scores is smaller in countries with greater gender equity. This submission is obvious in Nigeria because there is evidence of gender inequality.

\section{Implications of the Study}

Since there is no statistical significant difference in the academic achievement of students who were admitted into the university through remedial, unified matriculation examination 
and direct entry, these three methods ought to continue to be used as modes of entry into universities. For the very fact that there is no statistical significant difference in the mean academic achievement of students based on the modes of entry into the university, clearly implies that the achievement of the students in university education depends on the experiences of students under the influence of the university instructional environment. The implication of this study therefore is that students' academic success is largely a function of the amount of efforts put into study among other factors and not necessarily as a result of mode of entry into the university.

Since there is statistical significant difference in the mean academic achievement of male and female students who were admitted into the university through direct entry, remedial programme and unified tertiary matriculation examination admissions, this implies that there is an academic achievement gap between male and female students in the university system.

\section{Conclusion}

Based on the results of the study, it can be concluded that there is no statistical significant difference in the mean academic achievement of students who are admitted into the university through unified tertiary matriculation examination, remedial programme and direct entry. Therefore students do not differ significantly in their performance based on the mode of admission into the university. For the very fact that there is no statistical significant difference in the mean academic achievement of students based on the mode of entry into the university, clearly depicts that the achievement of the students in university education depends on the experiences of students under the influence of the university instructional environment.

There is a statistical significant difference in the mean academic achievement of male and female students who were admitted into the university through direct entry admission, remedial programme and unified tertiary matriculation examination. Hence the mean academic achievement of male students is higher than that of their female counterparts irrespective of the mode of admission into the university.

\section{Recommendations}

On the basis of the findings of this study, the following recommendations were made.

1. Since there was no statistical significant difference in the mean academic achievement of students who were admitted into the university through direct entry, unified tertiary matriculation examination and remedial programme, university authority should continue to admit students into the university through the three modes of admission at reasonable proportion to enhance the academic excellence of the citizenry

2. Efforts should be made by the university authority to ensure that none of the categories of students is discriminated against but treated the same way as others so as to produce good quality graduates.

Since there is statistical significant difference in the mean academic achievement of male and female students who were admitted into the university through direct entry admission, remedial programme and unified tertiary matriculation examination, attempt should be made to reduce the academic achievement gap between male and female students in universities. 
3. It is essential that that remedial programme be allowed to stay as a means of meeting up admission quota and addressing issues of imbalance

\section{References}

Adekunle, J. (2012). Nigerian students spend N160 billlion in Ghana universities. The Nation, p. 15. Retrieved from http://www.thenationonlineng.net/

Adeniyi, O. T. (2003). Academic performance of Nigerian students with different entry requirements Journal of Technical Teacher Education, 1 (3), 79-86

Agada, O. A. (2007). The Relationship between selected antecedent variables and academic Performance of students. African Journal of Education, 20 (3), 21-34.

Agbo, N. (2012). Joint Admission Matriculation Board reduces university admission to 180 marks. The Nation, $p .10$. Retrieved from http://www.thenationonlineng.net/

Aiken, L. R. (2007). Intellectual variables of mathematics achievement. Research Journal of School Psychology, 9, 201-206.

Angulu, E. I. (2005). Gender issue in the performance of student admitted through UME and pre- degree into Nigerian University. Educational Research, 2 (3), 46-48.

Becker, J. R. (2005). Differential treatment of females and males in mathematics classes. Journal of Research in Mathematics Education, 12 (3), 40-53.

Emaikwu, S. O., \& Nworgu, B. G. (2005). Evaluation of the context and presage variables in the implementation of further mathematics curriculum in Benue State. Journal of Educational Innovators, 1 (1), 7-16

Emaikwu, S. O. (2012). Assessing the effect of prompt feedback as a motivational strategy on students' achievement in secondary school mathematics. Journal of Educational Research, 3(4), 371-379.

Erickson, G. L. (2009). Females and science achievement. Journal of Science Education, 6B (2), 63-89.

Etukudo, U. E (2006). The effect of computer assisted instruction on gender and performance of junior secondary school in mathematics. ABACUS Journal of Mathematical Association of

Nigeria. 27 (1), 1-8

Ezema, T. U. (2006). A Comparison of the degree results of two-year and four-year students of business education, with implication for programme planning: A case study of University of Nigeria of Nuskka. Unpublished Thesis of University of Nigeria, Nuskka.

Finn, J. D. (2008). Sex differences in educational attainment. Harvard Education Review, 49, 477-503.

Fryer, R. G., \& Levitt, S. D. (2009). An empirical analysis of the gender gap in mathematics. American Economic Journal: American Economic Association, 2 (2), 210-240. Retrieved from www.nber.org/papers/w15238.

Glenn, E., \& Ashley, S. (2009). The Gender gap in secondary school mathematics at high achievement levels: Evidence from the American mathematics competitions. Journal of Economic perspective: American Economic Association, 24 (2), 109-128. Retrieved from www.nber.org/papers/w15238.

Guiso, L., Monte, F., Sapienza, P., \& Zingales, L. (2008). Culture, gender and mathematics. Science, 320, $1164-1169$.

Hyde, J. S., \& Mertz, J. E. (2009). Gender, culture, and mathematics performance. Proceedings of the National Academy of Science, 106 (22), 8801-8807.

Ipaye, T. (2004). Continuous assessment in school with some counseling applications. Ilorin: 
INTERNATIONAL JOURNAL OF ACADEMIC RESEARCH IN PROGRESSIVE EDUCATION AND

DEVELOPMENT

Vol. 1, No. 4, 2012, E-ISSN: 2226-6348 @ 2012 HRMARS

University of Ilorin press.

Long, T. O. (2005). Academic achievement of Nigerian undergraduates as a function of previous educational experiences. West African Journal of Education, 18 (2), 111-115.

Mgbake, S. O. (2006): Leading the self-managing school. London: Flamer Press.

National University Commission. (1999). Approved minimum academic standard. Ibadan: University Press.

Ojo, F. (2005). Nigerian Universities and high level manpower development. H.R.R.V research series. Lagos: University press. 21-23.

Onah, A. E. (2012). Effect of motivation on students' performance in mathematics. An undergraduate project submitted at the Federal University of Agriculture, Makurdi. 